\title{
“Kahramanın Kim?”: Okul öncesi dönem çocuklarının kahramanlarının incelenmesi
}

\section{"Who is the Hero?": Examining the heroes of preschool children}

\author{
Erhan Alabay ${ }^{1}$
}

\section{Makale Geçmişi \\ Geliş : 2 Şubat 2020 \\ Düzeltme : 15 Mart 2020 \\ Kabul : 16 Mart 2020}

\section{Makale Türü}

Araştırma Makalesi

\section{Article History}

Received : 2 February 2020

Revised : 15 March 2020

Accepted : 16 March 2020

\section{Article Type}

Research Article

\begin{abstract}
Öz: Bu araştırmanın amacı, 36-72 aylık çocukların kahraman özelliklerinin incelenmesidir. Araştırma karma model ile tasarlanmıştır. Araştırmanın çalışma grubunu, İstanbul ili Pendik ilçesinde özel ve resmi eğitim kurumlarında öğrenim gören 36-72 aylık toplam 200 çocuk oluşturmaktadır. Araştırmada, çocuklar ile bireysel olarak görüşülüp, öncelikle "kahraman" kavramı yaş seviyesine uygun olarak anlatılmıştır. Çocuklara görüşme esnasında 3 temel açık uçlu soru yöneltilmiştir. "Senin kahramanın kimdir?", "Kahramanının en sevdiğin özelliği nedir?" ve "Kahramanının özelliği sende olsa ne yapardın?" soruları çocuklara sorulmuştur ve çocukların verdikleri cevaplar ise görüşme formu üzerine yazılmıştır. Araştırma sonucunda, tüm çocuklardan alınan kahramanların \%96'sının belirgin bir cinsiyeti olduğu ve \% 71,5’inin ise erkek cinsiyetine sahip olduğu tespit edilmiştir. Araştırmaya katılan çocukların kahramanlarını büyük oranda aile bireylerinden ve çizgi film kahramanlarından seçtiği, kahraman olarak kitaplardaki karakterden çok az oranda seçtiği görülmüştür. Çocukların cinsiyet değişkeni ile kahramanlarının cinsiyetleri arasında anlamlı bir ilişkinin olduğu sonucuna ulaşılmıştır. Erkek çocuklar kadın kahramanları çok az oranda seçerken, kız çocuklar erkek kahramanları daha çok seçtiği görülmüştür.
\end{abstract}

Anahtar Kelimeler: Okul öncesi dönem, kahraman, çocuk.

Abstract: The aim of this research is to examine the characteristics of the heroes of 36-72 months old children. The study group of the research consists of a total of 200 children, 36-72 months old, who study at private and public educational institutions in Pendik district of Istanbul. In the research, individual interviews were made with the children. First of all, the concept of "hero" was explained to the children in accordance with the age level. During the interview, 3 basic open-ended questions were asked to the child. The questions are "Who is your hero?", "What is your favorite feature of your hero?" and "What would you do if you had the character of your hero?". The answers given by the children were written on the interview form. As a result of the research, $96 \%$ of the heroes chosen by children are heroes whose gender is certain. In addition, $71.5 \%$ of these heroes are men. It is observed that the children who participated in the research mostly chose their heroes from their family members and cartoon heroes, but as heroes they chose very little from the characters in the books. It was concluded that there was a significant relationship between the gender variable of the children and the sexes of their heroes. Finally, boys chose female heroes very little, while girls chose male heroes more.

Keywords: Pre-school period, Hero, Child.

\footnotetext{
${ }^{1}$ Sağlık Bilimleri Üniversitesi, Hamidiye Sağlık Bilimleri Fakültesi, Çocuk Gelişimi Bölümü, e-mail: erhan.alabay@sbu.edu.tr, ORCID: https://orcid.org/0000-0003-4025-2352
}

Atıf için/To cite this article:

Alabay, E. (2020). "Kahramanın Kim?”: Okul öncesi dönem çocuklarının kahramanlarının incelenmesi. Erken Cocukluk Çalısmalar Dergisi, 4(1), 152-171. doi: http://dx.doi.org/10.24130/eccd-jecs.1967202041224 


\section{SUMMARY}

\section{Introduction}

Individuals around the child constitute role models of children in preschool period. These role models are mostly family members. There are many role models, except for the family members, but. Especially as children get older, the child can choose the cartoon characters, TV series actors or book characters they have watched as role models. When we think that role models affect child's behavior positively or negatively, role models that children will choose are important. For example, while the mother of the person whom she took as a role model, while displaying the similarities of the words or behaviors made by the child mother; A child who takes a violent cartoon character as a role model can exhibit aggressive behavior. Therefore, role models of children affect the behavior of children, especially in preschool period.

In this context, the aim of the research is to examine the heroes of 36-72 months old children. In line with this main purpose, the following sub-goals are included:

- Who chose children as heroes?

- What features did children consider when choosing heroes?

- What would they do if the heroes chosen by the children had their own characteristics?

- Is there a significant relationship between the hero traits that children choose based on their gender and age?

\section{Method}

Both quantitative and qualitative methods were used in this research. Descriptive survey model, one of the quantitative research methods, was used. In this study, quantitative research was used to determine whether there is a significant relationship with the hero sub-themes of gender and age variable. The data collected in line with the interviews with children were used basic qualitative research. The study group of the research consists of a total of 200 children, 36-72 months old, who study at private and public educational institutions in Pendik district of Istanbul. Random sampling model was used in determining the schools. Only one age group from each school was included in the class research. Cluster sampling was used to determine the class. In this study, demographic information form and structured "Hero's Interview Form" developed by the researcher were used as data collection tool. "Hero's Interview Form" is a structured interview form developed by the researchers. This form covers the areas to write the questions to be asked to the child and the answers given by the child in individual interviews with each child. There are 3 open-ended questions in interview form. These questions are: "Who is your hero?", "What is your favorite feature of your hero?" and "What would you do if you had the character of your hero?". Content analysis was used in the analysis of data in the qualitative dimension of the research. In this study, the answers to three questions asked to children were examined, sub-themes were created and they were poured into percentage frequency tables. 
In the quantitative data analysis, the Chi-Square analysis was used to determine whether there is a significant relationship between the sub-themes created and the independent variables of the children.

\section{Results}

As a result of the research, it was concluded that $71.5 \%$ of the heroes chosen by children were male, $24.5 \%$ were female and $4 \%$ were genderless. In addition, heroes chosen by children are from $44.5 \%$ family members, $42.5 \%$ from cartoon heroes, $6.5 \%$ from people in the social circle, $3.5 \%$ from books in characters, and $3 \%$ from toy characters. It was found that $51.5 \%$ of the children chose heroes from real life and $48.5 \%$ chose a hero from an unrealistic life. It has been observed that the favorite features of the heroes of children are $79 \%$ of their operational characteristics. The action feature sub-theme is to create features such as flying, running fast. It was determined that $21 \%$ of the children chose their heroes because of their physical characteristics. It was concluded that $28.5 \%$ of the children who chose heroes for the study chose heroes for sexist reasons and $71.5 \%$ for non-sexist reasons. It was determined that $72 \%$ of children used for individual purposes and $28 \%$ used for social purposes in line with the characteristics of the heroes themselves. A meaningful relationship was found between the gender variable of the children and the gender of the hero, who the hero is, the relationship of the hero with the reality and the use of the character of the hero in himself. While $91.2 \%$ of boys chose heroes as men, only $2.9 \%$ chose female heroes. Girls chose both male and female heroes. It is seen that the heroes chosen by boys are mostly composed of cartoon heroes. 59.3\% of the girls were found to have chosen heroes from their family members. Another finding is that girls choose more real-life people as heroes than boys, while boys choose more imaginary heroes as heroes. Finally, while boys stated that they will use the negative features of the heroes they choose in $25.5 \%$ of their characteristics, this ratio drops to $5.1 \%$ in girls. There is no significant relationship between the age variable of the children and the hero characteristics of the children.

\section{Conclusion and Discussion}

In all kinds of publications for children, the number of female heroes should be increased or sexless heroes should be created. Trainings, conferences and workshops involving gender equality for children and their parents should be planned and applied to all socioeconomic parents. Cartoons that encourage the reduction of violent features of heroes, especially in the content of cartoons, and to bring prosocial behavior to children should be prepared. 


\section{GİRIŞ}

Çocuk sosyal bir varlıktır (Diken, 2010; Yavuzer, 2001). Bu nedenle çevresinde gerçekleşen her durumdan olumlu ya da olumsuz şekilde etkilenebilir. Özellikle doğduğu andan itibaren çocuğun sosyal çevresinde sadece aile bireyleri olurken, ilerleyen yıllarda bu sosyal çevresi genişler. Doğduğu anda bebek, fizyolojik ihtiyaçlarının karşılanması için anne ve babasına gereksinim duyar ve bu nedenle anne ve babası ile bir bağ kurar. Bu da bebeğin ilk sosyal ilişkileri olarak sayılır (Durualp ve Aral, 2011; Senemoğlu, 1994). Özellikle bebek, yürümeye ve formal bir eğitim almaya başladığ1 andan itibaren çocuğun çevresinde sosyal ilişkileri kurabileceği birey sayısı artmaktadır. Çocuk, çevresindeki bu bireyler tarafından içinde yaşadığ1 toplumun geleneklerini, göreneklerini, kültürel özelliklerini, toplumsal normları ve çocuğun davranışlarını etkileyecek olan değerleri öğrenir. $\mathrm{Bu}$ öğretiler çoğunlukla formal değil, informal olarak gerçekleşir (Günüç, Odabaş1, \& Kuzu, 2012; Rogers, 2005; Rogers, 2014; Werquin, 2010).

Çocuğun gelişimini etkileyen tek yap1 ailesi değildir. Bu doğrultuda Bronfenbrenner $(1979,1989)$ tarafindan savunulan "Ekolojik Sistemler Kuramı”na göre de çocuğun çevresindeki birçok yap1 çocuğun gelişimini ve davranışlarını etkiler. Kuramda çocuğun çevresinde bulunan yapıların, çocuğu doğrudan ya da dolaylı olarak etkileyeceği belirtilmiştir. Etkileyecek olan faktörleri belirli katmanlarda belirten Bronfenbrenner (1979, 1989), bu katmanları beş alt başlıkta incelemiştir (Shaffer, 2009). Ekolojik Sistemler Kuraminda farklı katmanların olma nedeni, bireylerin olgunlaşması ve gelişmesiyle birlikte, insanlar arası bilgi transferinin artması ve buna bağlı olarak davranışlarının değişmesi ile açıklanmaktadır. Kurama göre ilk katman çocuğun en çok etkileşimde olduğu mikrosistemdir. Bu sistem öncelikle ilk olarak aile ile başlayıp, ilerleyen süreçte karmaşık bir hal alır. Örneğin çocuk büyüdükçe farklı mikrosistemler ile tanısır (Parke, \& Clarke-Stewart, 2010). Arkadaş seçimleri, oyun aktiviteleri, ilgileri ve kişisel özellikleri doğrultusunda farklı bireyleri bu mikrosistemin içerisine dâhil eder. Özellikle çocuk okula başladığında, sınıf içinde farklı sosyal gruplara dâhil olur. Bu akran grupları, statü, prestij, dostluk, popülerlik gibi güçlü sosyal imkanlar sağlar (Rathus, 2011). Daha sonra gelen katman ise mezosistemdir. Mezosistem, aile - akranlar, aile - okul yönetimi ve aile- öğretmen arasındaki etkileşimi kapsarken, ardından gelen ekzosistemi ise, sosyal yapı, politik ve ekonomik sistem, eğitim sistemi, dini sistemler oluşturur. Makrosistemde ise medya/internet, gelenekler ve görenekler, kültürel değerler ve toplumsal normlar yer almaktadır. Son katman olan kronosistem ise zaman içinde değişen sosyo-tarihsel olayların ve sosyal koşulların, çocukların gelişimlerini etkilediğini belirten katmandır (Berns, 2012; Doğan, 2000; Kostelnik, Gregory, \& Whiren, 2011; Levine \& Munsch, 2010). 
“Ekolojik Sistemler Kuramı”na göre de görüldüğü üzere, çocuğun çevresinde bulunan birçok yap1 çocuğun davranışını ve kişiliğinin şekillenmesini etkilemektedir. Özellikle okul öncesi dönemde çocuğun davranışının ve kişiliğinin geliştiği en kritik dönemlerden birisidir. Bu dönemde çocuk, çevresinde bulunan bireyleri gözlemler, rol modeller seçebilir ve seçtikleri rol modellerin davranışlarını taklit edebilir. Bu rol modeller bazen ailesinden bireyler olabilmektedir. Tabi rol modeller yalnızca hayatımızın içerisindeki bireylerden seçilmemektedir. Özellikle çocuklarda yaş ilerledikçe izlemiş oldukları çizgi film karakterleri, dizi film oyuncuları veya bir kitap içerisindeki kurgu karakterleri rol model olarak seçebilmektedir. Çocuğun örnek aldığ1 rol modellerin davranışları çocuğun davranışını da etkilemektedir. Örneğin rol model olarak örnek aldığı kişi annesi ise, çocuk annesinin söylemiş olduğu sözlerin veya yapmış olduğu davranışların benzerlerini sergilerken; şiddet içerikli bir çizgi film karakterini rol model olarak alan bir çocuk ise saldırgan davranışlar sergileyebilmektedir. Bu nedenle özellikle okul öncesi dönemde çocukların rol modelleri çocukların davranışlarını etkilemektedir (Griffiths, \& Machin, 2003; Hamlen, \& Imbesi, 2019; Kampf, \& Hamo, 2015; Power, \& Smith, 2017).

Bu kapsamda araştırmanın amacı, 36-72 aylık çocukların rol model aldıkları kahramanları ve bu kahramanların özelliklerini incelemektir. Bu ana amaç doğrultusunda şu alt amaçlara yer verilmiştir:

- Çocuklar kahraman olarak kimleri seçmiştir?

- Çocuklar kahramanları seçerken hangi özellikleri dikkate almışlardır?

- Çocukların seçmiş oldukları kahramanların özellikleri kendisinde olsa neler yaparlardı?

- Çocukların cinsiyet ve yaşlarına göre seçtikleri kahraman özellikleri arasında anlamlı bir ilişki var midır?

\section{YÖNTEM}

$\mathrm{Bu}$ bölümde araştırmanın modeline, çalışma grubuna, veri toplama araçlarına, veri toplama süreçlerine, veri analizine ve geçerlik-güvenirliğe yer verilmiştir.

\section{Araştırma Modeli}

$\mathrm{Bu}$ araştırmada hem nicel hem de nitel yöntemden yararlanılmıştır. Nicel araştırma yöntemlerinden birisi olan betimsel tarama modeli bu araştırma için seçilmiştir. Karasar (2006)'a göre “betimsel tarama modeli araştırmalar, geçmiște ya da halen var olan bir durumu var olduğg sekli ile betimlemeyi amaç edinir" $\mathrm{Bu}$ araştırmada, çocukların kahraman alt temaları ile çocuğun cinsiyet ve yaş değişkeni arasında anlamlı bir ilişkinin olup olmadığının belirlenmesinde nicel araştırmadan faydalanılmıştır. Çocuklarla 
yapılan görüşmelerde toplanılan veriler ise nitel araştırma deseni toplanmışır. Nitel araştırma yöntemlerinden ise durum çalışması seçilmiştir. Durum çalışması, "güncel bir olgu veya durumu gerçek bir yaşam çerçevesi içinde çalışan, olgu ve içerik arasındaki sinurlarm kesin batlarylla belirgin olmadĭg ve birden fąla kanıt veya veri kaynağını mevcut olduğu durumlarda kullanılan” bir yöntemdir (Yıldırım, \& Şimşek, 2003).

\section{Çalışma Grubu}

Araştırmanın çalışma grubunu, İstanbul ili Pendik ilçesinde özel ve resmi eğitim kurumlarında öğrenim gören 36-72 aylık toplam 200 çocuk oluşturmaktadır. Okulların belirlenmesinde rastgele örnekleme modeline gidilmiştir. Belirlenen her bir okuldan sadece bir yaş grubu sınıf araştırmaya dâhil edilmiştir. Sınıf belirlenmesinde ise küme örneklemesine başvurulmuştur. Araştırma kapsamına alınan okul öncesi çocuklarının demografik özellikleri Tablo 1'de verilmiştir.

Tablo 1. Okul öncesi dönem çocuklarının demografik özellikleri

\begin{tabular}{llll}
\hline Demografik Bilgiler & & $\mathbf{n}$ & $\mathbf{\%}$ \\
\hline Cinsiyet & Kiz & 98 & 49,00 \\
& Erkek & 102 & 51,00 \\
\hline Yaş & $36-48$ ayllk & 57 & 28,50 \\
& $49-60$ ayllk & 45 & 22,50 \\
& 61-72 ayllk & 98 & 49,00 \\
\hline Okul öncesine devam etme & $0-12$ ay & 96 & 48,00 \\
süresi & 13 ay ve üzeri & 104 & 52,00 \\
\hline Anne öğrenim düzeyi & İlkokul & 25 & 12,50 \\
& Ortaokul & 15 & 7,50 \\
& Lise & 54 & 27,0 \\
& Üniversite & 106 & 53,00 \\
\hline Baba öğrenim düzeyi & Illkokul & 20 & 10,00 \\
& Ortaokul & 15 & 7,50 \\
& Lise & 45 & 22,50 \\
& Üniversite & 120 & 60,00 \\
\hline
\end{tabular}

Tablo 1 incelendiğinde, çalışma grubuna katılan çocukların \%51'inin erkek, \%49’unun kız olduğu görülmektedir. Yaş düzeyleri incelendiğinde, \%49’unun 61-72 aylık, \%28,50’sinin 36-48 aylık ve \%22,50'sinin ise 49-60 aylık yaş grubuna dâhil olduğu görülmüştür. Çalışmaya dâhil edilen çocukların \%52'sinin 13 ay ve daha fazla süredir, \%48'inin 0-12 ay arasında okul öncesi kuruma devam ettiği tespit edilmiştir. Annelerin ve babaların öğrenim durumları incelendiğinde, annelerin \%53'ünün üniversite, \%27'sinin lise, \%12,50'sinin ilkokul, \%7,50'sinin ortaokul mezunu; babaların ise $\% 60$ ’nın üniversite, $\% 22,50$ 'sinin lise, \%10'unun ilkokul ve $\% 7,5$ 'inin ortaokul mezunu olduğu sonucuna ulaşılmıştır. Araştırmaya katılan çocukların tamamının yaş ortalaması ise 56,46 ay olduğu 
tespit edilmiştir. Ayrıca çalışmada 100 çocuk devlet okulunda, diğer 100 çocuk ise özel okulda eğitim görmektedir.

\section{Veri Toplama Araçları}

$\mathrm{Bu}$ araştırmada veri toplama aracı olarak demografik bilgi formu ve araştırmacı tarafindan geliştirilmiş yapılandırılmış “Kahramanın Kim Görüşme Formu” kullanılmıştır.

\section{Demografik bilgi formu}

Çalışmada, çocuk hakkındaki genel demografik özelliklerin belirlenmesi amacıyla araştırmacı tarafından geliştirilmiş demografik bilgi formu kullanılmıştır. Demografik bilgi formu toplam 5 kapalı uçlu ve çoktan seçmeli sorudan oluşmaktadır. Demografik bilgi formu, çocuğun cinsiyeti, yaşı, okul öncesine devam etme süresi, anne ve baba öğrenim durumlan ile ilgili soruları içermektedir.

\section{Kahramanın kim görüşme formu}

Kahramanın kim görüşme formu, araştırmacılar tarafından geliştirilmiş yapılandırılmış bir görüşme formudur. Bu form, her çocukla yapılan bireysel görüşmelerde çocuğa sorulacak soruları ve çocuğun vermiş olduğu yanıtları yazabilecek alanları kapsamaktadır. Bu form öncelikle araştırmacı tarafından geliştirilmiş olup, 4 alan uzmanı öğretim elemanından görüşler alınmıştır. Alınan uzman görüşleri doğrultusunda gerekli düzenlemeler yapılmıştır. Ardından üç farklı yaş grubundan 1'er çocuk ile pilot çalışma gerçekleştirilmiştir. Pilot çalışmada soruların çocuklar tarafindan anlaşılıp anlaşılmadığı ve araştırmanın amacı doğrultusunda yanıtların alınıp alınmadığı denenmiştir. .

Kahramanın kim görüşme formunda toplamda 3 açık uçlu soru bulunmaktadır. Bu sorular şunlardır: a. Senin kahramanın kim? b. Kahramanının en sevdiğin özelliği nedir? c. Bu özellik sende olsa ne yapmak isterdin?

\section{Veri Toplama Süreçleri ve Analizi}

Çalışma 2018-2019 eğitim öğretim yılı kapsamında planlanmış ve uygulamaları gerçekleştirilmiştir. Çalışmaya başlamadan önce ulusal ve uluslararası yayınlar taranmış olup, gerekli dokümanlar incelenmiştir. Ardından çalışmanın önerisi hazırlanıp, gerekli izinler alınmıştır. Çalışmanın gerçekleştirileceği okul yöneticilerine ve ailelerine araştırmanın içeriği anlatılmış ve izin veren okullar ve izin veren ebeveynlerin çocukları ile çalışılmıştır. Çalışmanın veri toplama araçları 
geliştirildikten sonra belirlenen sınıfta görev yapan okul öncesi öğretmenlerinden randevular alınmış ve okullara gidilmiştir. Araştırmaya katılacak olan sınıflardaki çocuklardan daha samimi ve gerçekçi verilerin alınabilmesi amacıyla çalışmaya başlamadan önce araştırmacı tarafından belirlenmiş 2 oyun çocuklarla birlikte sınıflarında oynanmıştır. Böylelikle araştırmacı ile çocuk arasında bir etkileşim gerçekleştirilmiştir. Daha sonra araştırmacı sınıftaki çocuklara "Kahraman" kavramı tanımlanmıştır. Kahraman kavramı çocuklara "kahraman, sevdiğimiz özelliklerinden dolayı onun gibi olmak istediğimiz kişilerdir.” şeklinde açıklamıştır. Açıklamanın ardından çocuklarla boş bir sınıfta bireysel olarak görüşmeler gerçekleştirilmiştir. Görüşme formunda bulunan sorular çocuklara sorulmuş ve çocukların vermiş olduğu yanıtlar görüşme formuna yazılmıştır.

Araştırmanın nitel boyutunda verilerin analizi kısmında içerik analizinden yararlanılmıştır. İçerik analizi, nitel araştırmalarda sıklıkla kullanılan bir yöntemdir. Bu yöntemde veri setlerindeki veriler benzerlik durumlarına göre sayılır ve bunun oranları verilir (Silverman, 2001). Bu araştırmada da çocuklara sorulan üç sorunun cevapları incelenmiş olup, vermiş oldukları cevapların içerikleri incelenip alt temalar oluşturulmuştur. Alt temaların oluşturulması basamağında benzer araştırmalar incelenmiş ve alanyazına paralel şekilde alt temalar oluşturulmuştur. Oluşturulan alt temalar yüzde frekans tablolarına dökülmüştür. Nicel veri analizinde ise oluşturulan alt temalar ile çocukların bağımsız değişkenleri arasında anlamlı bir ilişkinin olup olmadığını tespit edebilmek amacıyla KiKare analizinden yararlanılmıştır.

Bulguların desteklenmesi hususunda çalışmada direk alıntılara yer verilmiştir. Çalışmaya katılan okul öncesi dönem çocuklarının bilgileri gizli tutulacağından dolayı ham verilere yer verilirken, kodlama sisteminden yararlanılmıştır. Bu doğrultuda görüşme sırası dikkate alınarak Ç1, Ç2, Ç3... şeklinde kodlama yapılmıştır.

\section{Geçerlik Güvenirlik}

Araştırmada kullanılan gözlem formu uzmanlar tarafindan incelenmiştir. Aynı zamanda veriler toplandıktan sonra başka bir uzman kişiden toplanılan verilerin içerik analizinin yapılması istenmiştir. Yapılan içerik analizleri araştırmacının yapmış olduğu içerik analizi ile karşılaştırılmışıı ve böylelikle gözlemciler arası tutarlığı hesaplanmıştır. Gözlemciler arası tutarllık, tutarlı olan madde sayısının toplam maddeye bölünüp, 100 ile çarpımından hesaplanır (Merriam, 2009). Çalışma kapsamında gözlemciler arası tutarlılık \% 094,56 olarak bulunmuştur. 


\section{BULGULAR}

\section{Çocuklar Kahraman Olarak Kimleri Seçmiştir?}

Görüşme formunun ilk sorusu olan "Senin kahramanın kim?” sorusuna alınan cevaplar cinsiyet, kim olduğu ve gerçekle ilişkisi durumlarına göre incelenmiş ve Tablo 2'de verilmiştir.

Tablo 2. Çocukların seçtikleri kahraman özellikleri

\begin{tabular}{llll}
\hline & & $\mathbf{n}$ & $\mathbf{0}$ \\
\hline Kahramanın cinsiyet & Kadın & 49 & 24,5 \\
& Erkek & 143 & 71,5 \\
& Cinsiyetsiz & 8 & 4,0 \\
\hline Kahramanın bulunduğu yer & Aile bireyi & 89 & 44,5 \\
& Çizgi film kahramanı & 85 & 42,5 \\
& Sosyal çevre & 13 & 6,5 \\
& Kitap & 7 & 3,5 \\
& Oyuncak & 6 & 3,0 \\
\hline Kahramanın gerçekle ilişkisi & Gerçek & 103 & 51,5 \\
& Gerçek dişı & 97 & 48,5 \\
\hline
\end{tabular}

Tablo 2 incelendiğinde, çocukların kahramanlarının \% 71,5'inin erkek, \%24,5'inin kadın ve \%4’ünün ise cinsiyetsiz olduğu; \%44,5'inin aile bireylerinden, \%42,5’inin çizgi film kahramanlarından, \%6,5’inin sosyal çevresindeki kişilerden, \%3,5’inin kitaplardaki karakterlerden ve \%3’ünün ise oyuncak karakterlerden seçtiği sonucuna ulaşılmıştır. Çocukların seçtikleri kahramanların gerçekle ilişkisi incelendiğinde ise, çocukların \%51,5’inin gerçek yaşamdan, \%48,5'inin ise gerçek olmayan hayali bir yaşamdan kahraman seçtikleri tespit edilmiştir.

\section{Çocuklar Kahramanları Seçerken Hangi Özellikleri Dikkate Almışlardır?}

Görüşme formunun ikinci sorusu olan "Kahramanının en sevdiğin özelliği nedir?” sorusu analiz edilmiş ve analiz sonuçları Tablo 3’te verilmiştir.

Tablo 3. Kahramanların en sevdikleri özellikler

\begin{tabular}{llll}
\hline & & $\mathrm{n}$ & $\%$ \\
\hline Kahramanın baskın özelliği & Fiziksel & 42 & 21,0 \\
& Eylemsel & 158 & 79,0 \\
\hline Seçilme nedeni & Cinsiyetçi & 57 & 28,5 \\
& Cinsiyetçi olmayan & 143 & 71,5 \\
\hline
\end{tabular}

Tablo 3 incelendiğinde, çocuklar kahramanların \%79’unun eylemsel özelliğini, \%21'inin ise fiziksel özelliğini sevdiğini belirtmiştir. Eylemsel özellik alt temasını uçmak, hızlı koşmak gibi özellikler oluşturmaktır. Çocukların \%21’i ise fiziksel özelliğinden kaynaklı kahramanını seçtiği tespit 
edilmiştir. Fiziksel özellik alt temasını ise kahramanın fiziksel görüntüsünden (saçı, boyu ve kıyafeti gibi) dolayı seçme nedenleri oluşturmaktadır. İkinci olarak çocukların kahramanlarını seçme nedenleri toplumsal cinsiyet açısından incelenmiştir. Bu bağlamda iki alt tema oluşmuştur. Bu alt temalar cinsiyetçi nedenler ve cinsiyetçi olmayan nedenlerdir. Cinsiyetçi nedenler alt temasını, yaşadığ1 toplumun kabul etmiş olduğu cinsiyet kalıplarını içeren cevaplar oluştururken; cinsiyetçi olmayan nedenler alt temasını ise cinsiyetçi herhangi bir kalıpyargısal düşüncenin olmadığı cevaplar oluşturmaktadır. Tablo 3'e bakıldığında, araştırmaya katılan çocukların kahramanları seçme nedenlerinin \%28,5'inin cinsiyetçi nedenlerden, \%71,5’inin ise cinsiyetçi olmayan nedenlerden dolayı seçtiği sonucuna ulaşılmıştır.

Örneğin 76. ve 116. sırada görüşme yapılan çocuklardan alınan verilerde anne ve babanın toplum tarafından kabul edilmiş cinsiyet kalıpyargılarını kahramanlık özelliği olarak belirtmiştir. 76. sıradaki çocuk "Kahramanım annem. Cok güzel yemek yapıyor. Bende yemek yapardım”, 116. siradaki çocuk "Babam. Güclü olması. Bende annemi korurdum.” şeklinde cevap vermiştir. Kadının yemek yapması, erkeğin ise güçlü olması şeklindeki kalıpyargıları çocukların kahramanlık özelliklerine yansıdığ1 görülmüştür.

\section{Çocukların Seçmiş Oldukları Kahramanların Özellikleri Kendisinde Olsa Neler Yapardı?}

Görüşme formunun üçüncü ve son sorusu olan “Bu özellik sende olsa ne yapmak isterdin?” sorusu analiz edilmiş ve analiz sonuçları Tablo 4'te verilmiştir.

Tablo 4. Kahramanların özellikleri sende olsa ne yapardın?

\begin{tabular}{llll}
\hline & & $\mathrm{n}$ & $\%$ \\
\hline Kullanma amac1 & Bireysel & 144 & 72,0 \\
& Toplumsal & 56 & 28,0 \\
\hline Kullanım yönü & Olumlu & 87 & 43,5 \\
& Olumsuz & 31 & 15,5 \\
& Nötr & 82 & 41,0 \\
\hline
\end{tabular}

Öncelikle çocuğun seçtiği kahramanının özelliklerinin çocukta olması halinde hangi amaçla kullandığı incelenmiştir. $\mathrm{Bu}$ aşamada çocukların vermiş oldukları cevaplar iki alt temada toplanmıştır. Bunlar bireysel amaçlı kullanım ve toplumsal amaçlı kullanım alt temalarıdır. Bireysel amaçlı kullanım alt teması çocuğun sadece kendisine dair kullanımı içeren cevapları kapsarken, toplumsal amaçlı kullanım alt teması ise çocuğun diğer insanları da amacın içerisine katan cevapları içermektedir. Tablo 4 incelendiğinde, çocukların \%72'sinin bireysel amaç, \%28'inin ise toplumsal amaç doğrultusunda kahraman özelliklerini kullandığı tespit edilmiştir. Aynı zamanda kahraman özelliklerini kullanma durumları kendi içerisinde olumlu, olumsuz ve nötr alt temalarına da ayrılmıştır. Çocukların kahraman özelliklerini \%43,5 oranında olumlu yönde kullanırken, \%15,5 
oranında olumsuz yönde kullandıklarını belirtmişlerdir. \%41 oranında ise kullanma yönünün nötr olduğu tespit edilmiştir.

Örneğin 74. sırada görüşme yapılan bir erkek çocuğu "Kahramanmm Süperman. En sevdiğim özelliği insanlar kurtarması. Bende insanlar kurtarırdım." cevabını vermiştir. Çocuğun yanıtı incelendiğinde, çocuğun kahraman özelliği kendisinde olması halinde toplumsal amaçlı olarak tüm insanları kurtarmak istediğini belirtmektedir. Özelliği kullanım yönü incelendiğinde ise olumlu bir amaç doğrultusunda kullandığ1 görülmektedir. Diğer bir örnek ise 172. sırada görüşme gerçekleştirilmiş bir kız çocuğunun cevabıdır. "Joker benim kahramanım. Sopa kullanması. İnsanlar döverdim." Kahramanı joker olan bir kız çocuğunun beğendiği özelliğin eylemsel bir yapıda ve bireysel bir özelliği olduğu anlaşılmaktadır. Fakat bu özelliğin kendisinde olması doğrultusunda olumsuz yönde kullanacağını belirtmiştir. Bu kapsamda bazı örnek ham veriler aşağıda verilmiştir.

Ç93. "Elsa benim kahramamm. En sevdiğim öz̧elliği kar yağdırması. Bende kar yağdırrdım."

Ç35. "Kardeşim Yusuf. Kzyafetlerini seviyorum. Kıyafetlerini giyerdim."

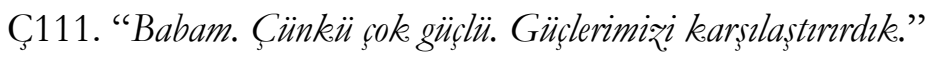

Ç21. "Rapunz̧el. Saçlarmm uð̧un olması. Evi olmayan hayvanlara saçlarmı yuva yapardım."

Ç187. "Süperman. Evleri yıkması. Bende bütün evleri ynkardım."

\section{Çocukların Cinsiyet ve Yaş Değişkeni ile Seçtikleri Kahraman Özellikleri Arasında Anlamlı}

\section{Bir İlişki Var Mıdır?}

Çalışmanın son alt problemi olan çocukların kahramanlarının özellikleri ile cinsiyet ve yaş değişkeni arasında anlamlı bir ilişki olup olmadığının belirlenmesi amacıyla Ki-Kare analizi uygulanmıştır. Cinsiyet ile kahraman seçimlerine ilişkin Ki-Kare analiz sonuçları Tablo 5’te verilmiştir.

Tablo 5. Çocukların cinsiyetleri ile kahraman özelliklerinin karşılaştırılması

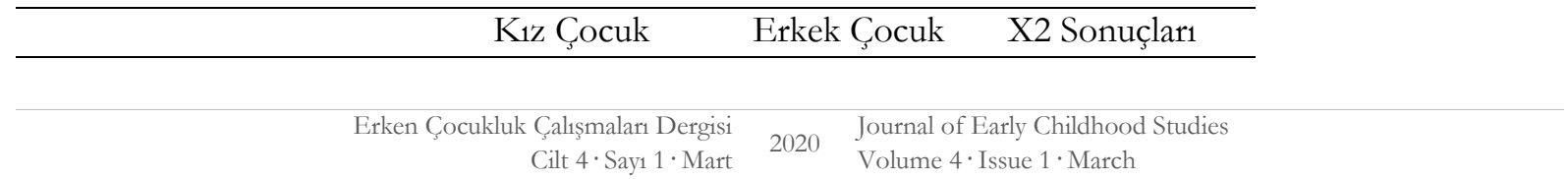




\begin{tabular}{|c|c|c|c|c|c|}
\hline & $\mathrm{n}$ & $\%$ & $\mathrm{n}$ & $\%$ & \\
\hline Kahramanın Cinsiyeti & & & & & X2: 52,606 \\
\hline Kadın & 46 & 46,9 & 3 & 2,9 & Sd: 2 \\
\hline Erkek & 50 & 51,0 & 93 & 91,2 & $\mathrm{p}:, 000^{*}$ \\
\hline Cinsiyetsiz & 2 & 2,1 & 6 & 5,9 & \\
\hline \multicolumn{6}{|l|}{ Kahramanı Kim } \\
\hline Aile Birevi & 58 & 59,3 & 31 & 30,3 & $\mathrm{X} 2: 37,551$ \\
\hline Çizgi Film Kahramanı & 22 & 22,4 & 63 & 61,8 & Sd: 4 \\
\hline Sosyal Çevre & 6 & 6,1 & 7 & 6,9 & $\mathrm{p}:, 000^{*}$ \\
\hline Kitap Karakteri & 6 & 6,1 & 1 & 1,0 & \\
\hline Oyuncak & 6 & 6,1 & - & - & \\
\hline Gerçekle İlişkisi & & & & & $\mathrm{X} 2: 19,320$ \\
\hline Gerçek & 66 & 67,3 & 37 & 36,3 & Sd: 1 \\
\hline Gerçek D1ş1 & 32 & 32,7 & 65 & 63,7 & $\mathrm{p}:, 000^{*}$ \\
\hline Özelliği Kullanım Yönü & & & & & X2: 22,365 \\
\hline Olumlu & 47 & 48,0 & 40 & 39,2 & Sd: 2 \\
\hline Olumsuz & 5 & 5,1 & 26 & 25,5 & $\mathrm{p}:, 000^{*}$ \\
\hline Nötr & 46 & 46,9 & 36 & 35,3 & \\
\hline
\end{tabular}

Tablo 5’ten de görüldüğü üzere çocukların cinsiyet değişkeni ile kahraman cinsiyeti, kahramanın kim olduğu, kahramanın gerçekle ilişkisi ve kahramanın özelliğini kendinde kullanma durumu arasında anlamlı bir ilişkiye rastlanmışır. Tabloya göre ilk bulgu çocukların cinsiyetleri ile seçtikleri kahramanların cinsiyetleri arasındadır. Erkek çocukların \%91,2'si kahramanları erkek olarak seçerken, sadece \%2,9’u kadın kahraman seçmiştir. Kız çocuklarının ise kahramanın cinsiyeti üzerine dağılımları birbirine oldukça yakındır. Kız çocuklarının seçtikleri kahramanların \%51’i erkek iken, \%49’u ise kadındır. Bu bulgu doğrultusunda erkek çocukların tamamına yakını sadece hemcins kahraman seçerken, kız çocukları her iki cinsiyetten kahramanları da seçmektedir. Anlamlı ilişkinin olduğu bir diğer bulgu ise erkek çocuklarının seçtikleri kahramanların en yoğun olarak çizgi film kahramanlarından oluştuğu görülmektedir. Kız çocuklarının \%59,3’ü ise aile bireylerinden kahraman seçtiği sonucuna ulaşılmıştır. Diğer bir bulgu ise kız çocukları, erkek çocuklarına göre daha fazla gerçek hayattan kişileri kahraman olarak seçerken, erkek çocukları daha fazla hayali kahramanları kahraman olarak seçmektedir. Son olarak erkek çocukları seçtikleri kahramanların özelliklerinin kendisinde olduğunda \%25,5’inde olumsuz yönden kullanacağını belirtirken, kız çocuklarda bu oran \%5,1'e düştüğü görülmektedir. Diğer bir ifade ile erkek çocukları kahramanın özelliklere sahip olduklarında kızlara oranla yaklaşık 5 kat daha fazla olumsuz davranış şeklinde sergileyeceğini belirtmiştir.

Çocukların cinsiyet değişkeni ile kahramanın baskın özelliği, cinsiyetçi olup olmama durumu ve kahraman özelliğini bireysel veya toplumsal olarak kullanma durumu arasında anlamlı bir ilişkiye rastlanmamıştır. Ayrıca çocukların yaş değişkeni ile tüm kahraman özellikleri arasında Ki-Kare analizleri yapılmış ve tüm kahraman özellikleri ile yaş değişkeni arasında anlamlı bir ilişkiye rastlanmamıştır. 


\section{SONUÇ ve TARTIŞMA}

36-72 aylık çocukların kahramanlarını ve bu kahramanların özelliklerini incelemek amacıyla yapılan bu çalışmada ilk bulgu, erkek çocuklarının tamamına yakınının hemcinsi kahramanları seçtiği gözlemlenirken, kız çocuklarının hem erkek hem de kadın kahramanlarını birbirine yakın oranlarda seçmiştir. Erkek çocuklarının tamamına yakınının erkek ve kız çocuklarının yarısından fazlasının erkek kahraman seçme nedenlerinden birisi ataerkil toplumlarda kahraman kavramlarının erkeklere atfedilmesinden ve bu nedenle çocukların karşılaştıkları durumlarda kahramanların çoğunlukla erkek olmasından kaynaklı olduğu düşünülebilir. Sezer (2010)’in masallar üzerinden toplumsal cinsiyet kalıplarını incelediği çalışmasında, masallarda erkeklerin genellikle kahramanlık yaparak kadınları kurtaran, kadınları ise kurtarılan olarak tasvir edildiği sonucuna ulaşılmıştır. Holub, Tisak ve Mullins (2008)'in ABD'de yaşayan çocukların seçtikleri kahramanlara atfettikleri cinsiyet farklılıklarını araştırmak üzere 10 yaş çocuklarıyla bir çalışma gerçekleştirmiştirler. Araştırma sonucunda, erkek çocuklarının kendi cinsiyetlerinde kahramanlar seçtiğini, kız çocuklarının ise farklı oranlarda hem kadın hem de erkek kahraman seçtiği tespit edilmiştir. Estrada, Martorell ve GarciaAel (2015) tarafından ABD, İspanya, Hong Kong, Katar ve Malezya ülkelerinden 13-19 yaş arası toplam 760 ergenin seçtikleri kahramanların özelliklerin belirlenmesi üzerine bir çalışma gerçekleştirilmiştir. Çalışma sonucunda ergenlerden alınan kahramanların çoğunluğunun erkek kahraman olduğu sonucuna ulaşılmıştır. Tüm kahramanların \%73,3'ünün erkek, \%26,7'sinin ise kadın kahraman olduğu tespit edilmiştir. Aynı zamanda kız çocuklarının erkek kahraman seçmesinin, erkek çocukların kadın kahraman seçme olasıllğından daha fazla olduğu görülmüştür. Alabay ve Yağan Güder (2015)'in oyuncak reklamlarındaki toplumsal cinsiyet yapısını inceledikleri çalışmasının bir bölümünde oyuncak reklam metinlerini analiz etmişlerdir. Analiz sonucunda erkeklere yönelik hazırlanmış olduğu düşünülen oyuncak reklamlarının metinlerinde çoğunlukla dünyayı kurtarma, maceracı, güçlü, kazanan ve kahraman gibi kavramların olduğu, kız çocuklarına yönelik hazırlanmış olduğu düşünülen oyuncak reklam metinlerinde ise çoğunlukla prenses olmak isteyen, sihir yapan, güzel olmaya çalışan, parti düzenleyen ve süslenen gibi kavramların olduğu bulunmuştur. Oyuncak reklamlarında da kahraman kavramının daha çok erkeklere yüklenen bir eylem olarak yansıtıldığı görülmüştür. Calvert, Kotler, Zehnder ve Shockeyy (2003) ve Glascock, (2001) tarafindan yapılan çalışmalarda çocuklara yönelik hazırlanmış programların içeriğindeki başrol ve baskın karakterlerin çoğunlukla erkek olduğunu sonucuna ulaşılmıstır. Hentges ve Case (2013)'in ilkokul çağı çocuklar için hazırlanmış olan televizyon programlarını inceledikleri çalışmasında, fiziksel ve sözel olarak sinirli yapıda olan, yardım eden, başkalarını kurtaran, otoriter ve komik olan karakterlerin \%66 oranında erkek karakterlere atfedildiği sonucuna ulaşılmıştır. Kaynak ve Aktaş (2017)'nn okul öncesi hikaye ve masal kitaplarında bulunan toplumsal cinsiyet 
rolleri üzerine yapmış olduğu çalışmada 50 adet hikaye ve masal kitabı incelemiştir. Araştırma sonucunda kitaplarda ve masallarda erkek karakterler kadın karakterlere göre daha araştırmacı, cesur, güçlü, kibirli ve saldırgan olarak tasvir edilmiştir. Gümüşoğlu (2008) ve Değirmenci ve Somer (2015) tarafından resimli kitaplardaki toplumsal cinsiyet rolleri üzerine gerçekleştirdikleri çalışmada da kitaplarda erkek karakterlerin, kadın karakterlerden nicelik olarak fazla olduğu ve çoğunlukla sorun çözme konumunda olan karakterlerin ise erkek karakterlerin olduğu sonucuna ulaşmıstır. Alpan Özdemir (2017) masallarda kadın kahramanlar bile olsa tipik zayıflıkları olduğunu belirtmiştir. Aynı zamanda masallardaki kadın karakterlerin şiddet mağduru, yoksul ve terk edilmiş gibi eylemlerin içerisinde olduğunu, erkek karakterin ise öperek iyileştirme gücü olduğu, savaşarak dünyayı kurtaran, düşmanı yenerek sarayları alan ve kadın karakterleri kötülerin elinden kurtaran özellikte olduğunu vurgulamıştır.

Çalışmanın bir diğer bulgusu da kız çocuklarının kahraman olarak seçtikleri kişilerin çoğunlukla kendi ebeveynlerinden olduğu, erkek çocukların ise çoğunlukla çizgi film kahramanlarından seçtiği tespit edilmiştir. Bu bulguya paralel olarak kız çocuklarının gerçek hayattan kahramanlar seçerken, erkek çocuklar hayali kahramanlar seçmektedir. Bunun nedenlerinden birisinin erkek çocuklarının kız çocuklara oranla daha fazla çizgi film izlemesi olarak düşünülebilir. Güngör ve Ersoy (1994) televizyon programlarının çocuklara etkisi üzerine anne ve baba görüşleri doğrultusunda gerçekleştirdiği çalışmasında da kız çocukların erkek çocuklara oranla daha az çizgi film izledikleri tespit edilmiştir. Anderson ve Cavallaro (2002)'nun çocukların rol modellerinde ve kahramanlarında ebeveynlerin mi popüler kültürün mü daha fazla etkisinin olduğunu araştırmada, popüler kültüründe en az ebeveynler kadar önemli etkisinin olduğunu saptamışlardır. Benzer bir çalışma da Oruç, Tecim ve Özyürek (2011) tarafindan yapılmıştır. Araştırmalarında okul öncesi dönem çocuklarının kişilik gelişimlerinde rol modellerini araştırmışlardır ve çocukların izledikleri çizgi filmlerden rol modeller aldığı sonucuna ulaşılmıştır. Aral, Ceylan ve Bıçakçı (2011) tarafından ilköğretim 4. ve 5. sınıf çocukları üzerine boş zamanlarını nasıl değerlendirdiklerini ortaya çıkarmak amacıyla gerçekleştirdiği çalışmalarında, erkek çocuklarının boş zamanlarını değerlendirmede ilk sırada televizyon izleme gelirken, kız çocuklarında ikinci sırada televizyon izleme gelmektedir. Aynı çalışmada erkek çocuklarının, kız çocuklarına oranla daha fazla çizgi film izledikleri sonucuna ulaşılmışır. Kız çocuklarının erkek çocuklarına oranla daha fazla aile bireylerini kahraman olarak seçme nedenlerinden birisi de özellikle çocukların gerçek hayatta veya oyun süreçlerinde daha fazla aile kavramı üzerinde yoğunlaşmasından kaynaklı olduğu düşünülebilir. Robinson ve Morris (1986) ile Tuzcuoğlu, Efe ve Güven (2006) yaptıkları çalışmalarda kız ve erkek çocuklarının oynadıkları oyuncakları oynama eğilimleri incelenmiştir ve kız çocukların çoğunlukla evcilik oyunları oynadıkları sonucuna varılmıştır. Bu noktada ebeveynlerin de özellikle etkili olduğu görülmüştür. 
Özellikle çocuklara seçmiş oldukları oyuncaklar da bu oyun süreçlerini etkilemektedir. Atav Ülker, İkiz, Uyar ve Yakar (2018)'in 36-72 aylık çocuğu olan ebeveynlerin oyuncak seçimleri üzerine yaptığ1 araştırma sonucunda da, kız çocuklarına en çok bebek, erkek çocuklarına ise en çok araba tercih edilmektedir. Bu bağlamda benzer birçok araştırmaya rastlanmaktadır (Bağçeli Kahraman, \& Başal, 2011; Bolışık, Bal Yılmaz, Yavuz, \& Tural Büyük, 2014; Çelebi Öncü, \& Ünlüer, 2012; Yağan Güder, \& Alabay, 2016). Aynı zamanda kız çocuklarının daha fazla aile, erkek çocuklarının ise daha çok çizgi film karakterlerini kahraman olarak seçmesinde ebeveynlerin de rollerinin etkili olduğu söylenebilir. Aksoy ve Baran (2017)'1n annelerin cinsiyet rollerine ilişkin özellikleri ile çocukların oyuncak tercihleri ve oynadıkları oyun türleri arasındaki ilişkiyi araştırdıkları çalışmasında, feminen ve maskülen annelerin çocuklarının oyuncak seçimleri ile androjen annelerin oyuncak seçimleri arasında bir farklılaşma olduğunu tespit etmiştir. Feminen özellikteki annelerin kız çocukları daha fazla evcilik oyuncaklarını, maskülen özellikte olan annelerin erkek çocuklarının ise daha çok oyuncak araçları tercih ettiği görülmüştür. Androjen annenin her iki cinsiyetteki çocuklarının oyuncak seçimlerindeki cinsiyet ayırımları azalmıştır. Alabay, Toprakkaya, Dörtyama, Baltacı, Şavşet, Bozkurt ve Kıyaker (2014)'in okul öncesi dönemde çocuğu olan ebeveynlerin eğitimde toplumsal cinsiyet rollerine ilişkin rollerini inceledikleri çalışmasında ebeveynlere "erkek çocuğunuðฺn

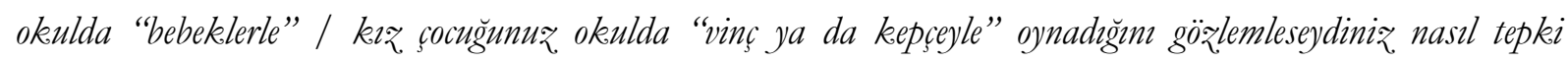
verirdiniz?" sorulmuş ve ebeveynlerin yaklaşı \%30'unun olumsuz ve şüpheci yaklaşımlar sergileyeceği sonucuna ulaşılmıştır.

Çalışmanın bir diğer bulgusu da, erkek çocukları seçtikleri kahramanların özelliklerinin kendisinde olduğunda \%25,5’inde olumsuz yönden kullanacağını belirtirken, kız çocuklarda bu oran \%5,1'e düştüğü tespit edilmiştir. Bunun nedenlerinden birisinin erkek çocuklanının kahramanlarının çoğunlukla çizgi film kahramanları olmasından kaynaklı olabilir. Nathanson (1998) ve Boyatzis, Matillo ve Nesbitt (1995)'in yapmış oldukları çalışmalarda televizyonda izlemiş olduğu programların çocukların saldırganlık özelliğini tetikleyeceğini ve kız ve erkek çocuklarında aynı etkileri ortaya çıkarmadığını belirtmiş̧tir. Özellikle kız ve erkek çocukları saldırgan eğilimli programlar izlediklerinde kız çocuklarının izledikleri saldırgan davranışlardan etkilenmediği, erkek çocuklarının ise kız çocuklarına oranla daha fazla izledikleri saldırgan davranışları oyunlarında sergilediği gözlemlenmiştir. Peter ve Blumberg (2002) ABD’de yayımlanan 2757 programın içeriğinin şiddet öğeleri açısından incelemek amacıyla yapmış olduğu çalışmada, çocuklara yönelik hazırlanmış olan programların \%69'unda şiddet öğesinin bulunduğunu saptamıştır. Yaşar ve Paksoy (2011)'un çizgi filmlerdeki saldırgan davranışların 5 yaş çocukların serbest oyunlarına yansımalarını incelediği çalışmada, çocuklar çizgi filmden izlemiş olduğu saldırgan davranışları serbest oyun başlangıçlarında sergilediği tespit edilmiştir. Kassay (2019)'ın çizgi film kahramanlarının çocuklardaki eğilimini 
araştırdıkları çalışmasında, çizgi filmlerdeki cinsiyetçi kahramanların cinsiyetsiz kahramanlardan daha fazla olduğu ve cinsiyetçi kahramanların çocukların üzerine daha fazla olumsuz etki yaptığ sonucuna ulaşmışlardır. Fakat ebeveynlerin eğitim durumu yükseldikçe bu etkinin azaldığ1 saptanmıştır.

Çalışmada bulunan bir diğer bulgu ise kahraman özelliklerinin çocuklar tarafından daha çok bireysel olarak kullanılmasıdır. Bu durumun en önemli nedenlerinden birisinin 60-72 aylık çocukların gelişimsel nedenlerinden kaynaklı olduğu düşünülebilir. White ve O'Brien (2010)'in kahramanın kim adlı çalışmasında anaokulundan 12. sınıfa kadar toplam 590 çocuğun kahramanlarını ve bu kahramanların özelliklerini araştırdığı çalışmasında da benzer sonuca ulaşmıştır. Çalışma sonucunda 5-6 yaşlarındaki çocukların kahramanlarındaki temel kahraman özelliğinin insanları kurtarması olduğu ortaya çıkarken, temel vurgunun kahramanlarının süper güçleri olduğudur. 8-9 yaşındaki çocuklara gelindiğinde ise bireyi kurtarmanın dışında diğer bireylere de yardım etmenin önemli olduğu sonucuna ulaşılmıştır.

Genel bulgular doğrultusunda bu araştırma ile ilgili olarak şu önerilerde bulunulabilir:

- Çocuklara yönelik her türlü yayınlarda kadın kahramanların sayısının arttırılması veya cinsiyetsiz kahramanların oluşturulması gerekmektedir.

- Çocuklara ve ebeveynlerine yönelik toplumsal cinsiyet eşitliğini içeren eğitimler, konferanslar ve atölyeler planlanmalı ve tüm sosyoekonomik düzeydeki ebeveynlere uygulanmalidir.

- Özellikle çizgi filmlerin içeriğinde bulunan kahramanların şiddet içerikli özellikleri kaldırılmalı ve çocuklara prososyal davranışlar kazandırmayı özendiren çizgi filmler hazırlanmalıdır.

- Araştırmacılar, kültürel, inanç, sosyoekonomik durum, yaşadığ1 yer, gelenek ve görenekler gibi farklı değişkenleri de göz önünde bulundurarak, daha büyük çalışma grupları ile nitel, nicel veya karma çalışmalar gerçekleştirmelidir.

\section{KAYNAKÇA}

Aksoy, P., \& Baran, G. (2017). Annelerin cinsiyet rollerine ilişkin özellikleri ile çocukların oyuncak tercihleri ve oynadıkları oyun türleri arasındaki ilişki üzerine bir çalışma. Eğitimde Nitel Araşttrmalar Dergisi, 5(1), 102-136. 
Alabay, E., \& Yağan Güder, S. (2014). Oyuncak reklamlarmm mesajı: "Bana cinsiyetini söyle, sana oyuncağzm söyleyeyim...” Akdeniz Üniversitesi I. Dil, Kültür ve Edebiyat Çalıştayı, 5 Haziran 2015, Antalya, 1-16.

Alabay, E., Toprakkaya, İ. M., Dörtyama, G., Baltacı, E., Şavşet, S., Bozkurt, D. ve Kıyaker, S. (2014). Okul öncesi dönem çocuğg olan ebeveynlerin eğitimde toplumsal cinsiyet ayrmmciluğ ile ilgili görüslerinin incelenmesi. VI. Uluslararası Türkiye Eğitim Araştırmalar1 Kongre Kitabı, 5-8 Haziran 2014, Ankara, 657-672.

Alpan Özdemir, E. D. (2017). Toplumsal cinsiyet kalıp yargılarının çocuk oyunlarına yansıması. GSF Sanat Dergisi, 31, 80-89.

Anderson, K. J., \& Cavallaro, D. (2002). Parents or pop culture? Children's heroes and role models. Childhood Education, 78(3), 161-168.

Aral, N., Ceylan, R.., \& Bıçakçı M. Y. (2011). Çocukların televizyon seyretme alışkanlıklarının yaş ve cinsiyete göre incelenmesi. Kastamonu Ë̈itim Dergisi, 19(2), 489-498.

Atav Ülker, P., İkiz, S., Uyar, G., \& Yakar, N. (2018). 3-6 yaş grubu çocuğa sahip ebeveynlerin oyuncak seçme ve kullanma stratejileri. Karabüle Üniversitesi Sosyal Bilimler Enstitüsü Dergisi, Özel Say1 4, 64-77.

Bağçeli Kahraman, P., \& Başal, H.A. (2011). Anne eğitim düzeyine göre çocukların cinsiyet kalıpyargiları ile oyun ve oyuncak tercihleri. e-Journal of New World Sciences Academy, 6(1), 3658.

Berns, R. M. (2012). Child, family, school, community: Socialization and support. USA: Wadsworth Publishing.

Bolış1k, B., Bal Yılmaz, H., Yavuz, B., \& Tural Büyük, E. (2014). Yetişkinlerin çocuklar için oyuncak seçimine yönelik davranışlarının incelenmesi. Gümüşhane Üniversitesi Sağllk. Bilimleri Dergisi, 3(4), 976-990.

Boyatzis, C. J., Matillo, G. M., \& Nesbitt, K. M. (1995). Effects of the "Mighty Morphin Power Rangers" on children's aggression with peers. Child Study Journal, 25(1), 45-55.

Bronfenbrenner, U. (1979). Contexts of child rearing: Problems and prospects. American Psychologist, 34, 844-850.

Bronfenbrenner, U. (1989). Ecological systems theory. Annals of Child Development, 6, 187-249.

Calvert, S. L., Kotler, J. A., Zehnder, S. M., \& Shockey, E. M. (2003). Gender stereotyping in children's reports about educational and informational television programs. Media Psychology, 5(2), 139-162.

Çelebi Öncü, E., \& Ünlüer, E. (2012). Preschoolers' views about gender related games and toys. Procedia - Social and Behavioral Sciences, 46, 5924 - 5927.

Değirmenci, G. Y., \& Somer, B. (2015). Resimli çocuk kitaplarmın toplumsal cinsiyet kavramı açısından incelenmesi. II. International Eurasian Educational Research Congress, 8-10 Haziran 2015, Ankara. 
Diken, H. İ. (2010). Erken çocukluk eğitimi(1. Baskı).Ankara: Pegem Akademi Yayınevi.

Doğan, A. (2000). Ekolojik sistemler kuramı çerçevesinde akran zorbalı̆̆ının incelenmesi. Çocuk ve Gençlik Rub Sağhl̆ğ Dergisi, 17(3), 149-162.

Durualp, E., \& Aral, N. (2011). Oyun temelli sosyal beceri eğitimi (1. Baskı). Ankara:Vize Yayıncilık.

Estrada, J. D., García-Ael, C., \& Martorell, J. L. (2015). Gender differences in adolescents' choice of heroes and admired adults in five countries. Gender and Education, 27(1), 69-87.

Glascock, J. (2001). Gender roles on prime-time network television: Demographics and behaviors. Journal of Broadcasting \& Electronic Media, 45(4), 656-669.

Griffiths, M., \& Machin, D. (2003) Television and playground games as part of children's symbolic culture. Social Semiotics, 13(2), 147-160.

Gümüşoğlu, F. (2008). Ders kitaplarında toplumsal cinsiyet. Toplum ve Demokrasi, 2(4), 39-50.

Güngör, A., \& Ersoy, Ö. (1994). Televizyon programlarnm okul öncesi dönem çocuklarna etkisine iliskin anne-baba görüsleri, 10.YA-PA Okul Öncesi Eğitimi ve Yaygınlaştırması Semineri, Ankara.

Günüç, S. , Odabaşı, H., \& Kuzu, A. (2012). Factors affecting lifelong learning. Gaz̧iantep University Journal of Social Sciences, 11(2), 309-325.

Hamlen, K. R., \& Imbesi, K. J. (2020). Role models in the media: A content analysis of preschool television programs in the U.S. Journal of Children and Media, 14(3), 1-22.

Hentges, B., \& Case, K. A. (2013). Gender representations on disney channel, cartoon network, and nickelodeon broadcasts in the United States. Journal of Children and Media, 7(3), 319333.

Holub, S., Tisak, M., \& Mullins, D. (2008). Gender differences in children's hero attributions: personal hero choices and evaluations of typical male and female heroes. Sex Roles. 58(7-8), 567-578.

Kampf, Z., \& Hamo, M. (2015). Children talking television: The salience and functions of media content in child peer interactions. Discourse \& Communication, 9(4), 465-485.

Karasar, N. (2006). Bilimsel araştırma yöntemi. Ankara: Nobel yayın Dağıtım.

Kassay, R. (2019). Barbie princesses and Star Wars clones: gender stereotypes in the representation of children's favourite heroes-a participant study in urban and rural contexts, among Hungarians from Romania. Feminist Media Studies, 19(5), 684-701.

Kaynak, D., \& Aktaş, E. (2017). Okul öncesi hikaye ve masal kitaplarında toplumsal cinsiyet rolleri. Ekev Akademi Dergisi, 21(72), 67-85.

Kostelnik, M. J., Gregory, K. M., Soderman, A. K., \& Whiren, A. P. (2011). Guiding children's social development and learning. USA: Cengage Learning Custom Publishing. 
Levine, L. E., \& Munsch, J. A. (2010). Child development: An active learning approach. USA: Sage Publications.

Merriam, S. B. (2009). Qualitative research A guide to design and implementation. San Francisco, CA: Jossey-Bass.

Nathanson, A. I. (1998). The immediate and cumulative effects of television mediation on children's aggression. Yayımlanmamıs Doktora Tezi, University of Wisconsin-Madison.

Oruç, C., Tecim, E., \& Özyürek, H. (2011). Okul öncesi dönem çocuğunun kişilik gelişiminde rol modellik ve çizgi filmler. EKEV Akademi Dergisi, 15(48), 303-319.

Parke, R. D., \& Clarke-Stewart, A. (2010). Social development. USA: RRD/Jefferson City.

Peters, K. M., \& Blumberg, F.C. (2002). Cartoon violence: Is it as detrimental to preschoolers as we think? Early Childhood Education Journal, 29(3),143-148.

Power, S., \& Smith, K. (2017). 'Heroes' and 'villains' in the lives of children and young people. Discourse Stud. Cult. Polit. Edu., 38, 590-602.

Rathus, S. A. (2011). Childhood \& adolescence: Voyages in development. USA: Wadsworth Cengage Learning.

Robinson, C. C., \& Morris, J. T. (1986). The gender-stereotyped nature of Christmas toys received by 36-, 48-, and 60-month-old children: A comparison between nonrequested vs. requested toys. Sex Roles, 15, 21-32.

Rogers, A. (2005). Non-formal education: Practical schooling or participatory education. Boston, MA: Springer.

Rogers A. (2014), The base of the iceberg. Informal learning and its impact on formal and nonformal learning, Verlag Barbara Budrich, Opladen; Berlin; Toronto, available at http://nbnresolving.de/urn:nbn:de:0111-pedocs-148444, accessed 21 December 2019.

Senemoğlu, N. (1994). Okul öncesi eğitim programı hangi yeterlilikleri kazandırmaktadır? Hacettepe Üniversitesi Ë̈itim Fakültesi Dergisi, 10, 10-25.

Sezer, M. Ö. (2010). Masallar ve toplumsal cinsiyet. İstanbul: Evrensel Yayınlar1.

Shaffer, D. R. (2009). Social and personality development. USA: Wadsworth Cengage Learning.

Silverman, D. (2001). Interpreting qualitative data, methods for analyzing talk, text and interaction (2nd ed.). London: Sage Publication Inc.

Tuzcuoğlu, N., Güven, .G., \& Efe, K. (2006). 4-6 Yas grubu çocuklarinda oyuncak terciblerini etkileyen faktörlerin incelenmesi. Marmara Üniversitesi Atatürk Eğitim Fakültesi 1. Uluslararası Okul Öncesi Eğitim Kongresi, İstanbul, Bildiri Kitabı: 1.Ya-Pa Yayınc1lı, 455-473.

Werquin, P. (2010). Recognising non-formal and informal learning: Outcomes, policies and practices. OECD Publications. 
White, S. H., \& O'Brien, J. E. (1999). What is a hero? An exploratory study of students' conceptions of heroes. Journal of Moral Education, 28(1), 81-95.

Yağan Güder, S., \& Alabay, E. (2016). 3-6 yaş arasındaki çocukların oyuncak tercihlerinin toplumsal cinsiyet bağlamında incelenmesi. Abi Evran Üniversitesi Kirşehir Eğitim Fakültesi Dergisi (KEFAD), 7(2), 91- 111.

Yaşar, M., \& Paksoy, İ. (2011). Çizgi filmlerdeki saldırgan içerikli görüntülerin çocukların serbest oyunları sırasındaki saldırganlık düzeylerine etkisi. Cukurova Üniversitesi Sosyal Bilimler Enstitüsü Dergisi, 20(2), 279-298.

Yavuzer, H. (2001). Cocuk psikolojisi (20. Baskı). İstanbul: Remzi Kitapevi. 